\title{
Ichthyoplankton-based spawning dynamics of blue mackerel (Scomber australasicus) in south-eastern Australia: links to the East Australian Current
}

\author{
FRANCISCO J. NEIRA* AND JOHN P. KEANE \\ Marine Research Laboratories, Tasmanian Aquaculture $\mathbb{E}$ \\ Fisheries Institute, University of Tasmania, Private Bag 49, \\ Hobart, Tas. 7001, Australia
}

\begin{abstract}
We describe findings of three ichthyoplankton surveys undertaken along south-eastern Australia during spring (October 2002, 2003) and winter (July 2004) to examine spawning habitat and dynamics of blue mackerel (Scomber australasicus). Surveys covered $\sim 860$ nautical miles between southern Queensland (Qld; 24.6 ${ }^{\circ}$ ) and southern New South Wales (NSW; $41.7^{\circ} \mathrm{S}$ ), and were mainly centred on the outer shelf including the shelf break. Egg identifications were verified applying mtDNA barcoding techniques. Eggs $(n=2971)$ and larvae $(n=727$; $94 \%$ preflexion $)$ occurred both in spring and winter, and were confined to 25.0-34.6 ${ }^{\circ} \mathrm{S}$. Greatest abundances (numbers per $10 \mathrm{~m}^{2}$ ) of eggs (1214-7390) and larvae (437-1172) occurred within $10 \mathrm{~nm}$ shoreward from the break in northern NSW. Quotient analyses on egg abundances revealed that spawning is closely linked to a combination of bathymetric and hydrographic factors, with the outer shelf as preferred spawning area, in waters $100-125 \mathrm{~m}$ deep with mean temperatures of $19-20^{\circ} \mathrm{C}$. Eggs and larvae in spring occurred in waters of the East Australian Current (EAC; $20.6-22.3^{\circ} \mathrm{C}$ ) and mixed (MIX; $18.5-19.8^{\circ} \mathrm{C}$ ) waters, with none occurring further south in the Tasman Sea (TAS; $16.0-17.0^{\circ} \mathrm{C}$ ). Results indicate that at least some of the south-eastern Australian blue mackerel stock spawns during winterspring between southern Qld and northern NSW, and that no spawning takes place south of $34.6^{\circ} \mathrm{S}$ due to low temperatures $\left(<17^{\circ} \mathrm{C}\right)$. Spawning is linked to the EAC intrusion, which also facilitates the southward transport of eggs and larvae. Since spring peak egg abun-
\end{abstract}

*Correspondence. e-mail: francisco.neira@utas.edu.au

Received 22 May 2007

Revised version accepted 24 March 2008 dances came from where the EAC deflects offshore, eggs and larvae are possibly being advected eastwards along this deflection front. This proposition is discussed based on recent data on blue mackerel larvae found apparently entrained along the Tasman Front.

Key words: East Australian Current, eastern Australia, ichthyoplankton, pelagic fishes, Scomber australasicus, shelf spawning

\section{INTRODUCTION}

The spatio-temporal characterization of spawning habitats of fishes is becoming an increasingly important task of fishery science, particularly in the context of biomass estimates and subsequent predictions of recruitment success and stock health (e.g. Checkley et al., 1999; van der Lingen et al., 2001, 2005; Ibaibarriaga et al., 2007). More importantly, such information underpins any future evaluation of likely changes to stock distribution and abundance associated to the looming global climate change scenario (IPCC; http://www.ipcc.ch; last accessed 1 November 2007). In the case of small pelagic fishes, the definition of spawning habitat requires coupling between sound biological data, such as eggs and larvae, and high resolution oceanographic data (van der Lingen et al., 1998, 2001, 2005), while changes in biomass can be assessed with techniques such as the daily egg production method (DEPM) (Stratoudakis et al., 2006). Key factors required to define spawning habitats of small pelagic fishes include hydrography, especially water column temperature, and shelf bathymetry (Checkley et al., 1999; Ibaibarriaga et al., 2007).

Mackerels of the genus Scomber support large commercial and recreational fisheries in tropical and temperate marine waters worldwide (Collette and Nauen, 1983). Of the three known mackerels traditionally placed in Scomber (excluding the recently resurrected S. colias; Infante et al., 2007), the spawning habitat and dynamics of S. australasicus (hereafter termed 'blue mackerel') are the least known. This includes limited information on the spatial and 
temporal distribution of their eggs and larvae (e.g. Crossland, 1981, 1982), and key aspects of its reproductive biology. By contrast, S. japonicus and S. scombrus, neither of which occur in Australian waters, are known to exhibit complex spawning patterns that include age-dependent maturity and age/ sex-dependent seasonal spawning migrations of separate stocks (Ware, 1977; Ware and Lambert, 1985; Dawson, 1986; de Lafontaine and Gascon, 1989; Scoles et al., 1998; Studholme et al., 1999; Table 1). In terms of spawning mode, all Scomber are pelagic batch (serial) spawners, and produce pelagic, buoyant eggs which makes them ideal targets for the DEPM (Morse, 1980; Lockwood et al., 1981; Collette and Nauen, 1983; Dickerson et al., 1992; Studholme et al., 1999).

The demand for blue mackerel in Australia has steadily increased during the last decade, with most purse-seine catches currently used as tuna feed for the growing number of farms (Ward et al., 2001). However, despite its growing importance, there is almost no data available on the distribution and abundance of their eggs or larvae, or on key spawning areas and season (Bruce and Bradford, 2002). In this paper we describe the spatial distribution and abundance of eggs and larvae of blue mackerel based on data collected during three intensive ichthyoplankton surveys conducted over shelf waters of south-eastern Australia between October 2002 and July 2004. The surveys were primarily designed to obtain data on egg and larval distribution, and use this information at a later stage to design adequate sampling strategies to estimate spawning biomass of the species via the DEPM. This technique relies on prior knowledge of daily egg production and size of spawning area from intensive egg collections (Stratoudakis et al., 2006), and has been applied to S. scombrus (Priede and Watson, 1993) and S. japonicus (Watanabe et al., 1999), but not blue mackerel.

We focus on timing and area(s) of spawning, and examine the data in terms of environmental conditions, including field-collected data and sea-surface temperature (SST) images for each area and survey period. Results are discussed in relation to possible linkages between abundances of eggs and larvae, and water masses present along the shelf area during the survey periods, including regional oceanography (e.g. upwelling). Work concurrent to this study (Keane and Neira, 2008) described three water masses over the shelf area surveyed, namely East Australian Current (EAC) and Tasman Sea, and mixed water in between. The EAC constitutes the main hydrographic feature off eastern Australia, carrying warm, low-nutrient tropical water southwards (Ridgway and Godfrey, 1997) which triggers nutrient enrichment of shelf waters (Tranter et al., 1986; Hallegraeff and Jeffery, 1993; Oke and Middleton, 2001). Finally, we propose a spawning strategy for blue mackerel off south-eastern Australia and, when appropriate, compare spawning habitat and dynamics of this species with those described for S. japonicus and S. scombrus (Table 1).

\section{METHODS}

\section{Survey area}

The area surveyed encompassed some 860 nautical miles $(\mathrm{nm})$ of the eastern Australian shelf region between $24.6^{\circ} \mathrm{S}$ and $37.5^{\circ} \mathrm{S}$, which included the southern portion of Queensland (Qld) and entire New South Wales (NSW) (Fig. 1). Surveys were conducted along southern Qld to the tip of southern NSW in October 2002 and 2003 (spring) and southern Qld to mid-NSW in July 2004 (winter) (Table 2). Results of two additional surveys carried out in February 2003 and February 2004 (summer) along shelf waters between southern NSW and mideastern Tasmania are not reported here since they yielded no eggs or larvae of blue mackerel (F.J. Neira, unpublished data). Survey dates were initially chosen following larval and adult reproductive data indicating that spawning of this species in eastern Australia takes place mostly in winter-summer (Drs M. Lowry and A.G. Miskiewicz, personal communication).

Sampling effort, i.e. number of transects and stations, depended on region size and vessel time available per survey. Surveys covered a grid of 3-7 across-shelf stations every $5 \mathrm{~nm}$ along 10-21 transects set perpendicularly to the coast every $20-50 \mathrm{~nm}$, as well as 1-3 along-shelf stations between transects in three of the five surveys. Additional along-shelf stations in October 2002 were placed between all 15 transects, whereas in October 2003 they were restricted to the northern-most six transects. Acrossshelf stations sampled in October 2002 and 2003 were each located $10 \mathrm{~nm}$ and $5 \mathrm{~nm}$ shoreward from the shelf break, at the shelf break and $5 \mathrm{~nm}$ offshore from the break. In July 2004 stations were positioned every $5 \mathrm{~nm}$ from the shelf break to the shore except for transects 1 and 3-5 where stations were placed every $10 \mathrm{~nm}$ due to the shelf width. Six stations were omitted during surveys due to bad weather, including five in October 2002. In all, a total of 256 samples were collected across all three surveys (Table 2).

(c) 2008 The Authors, Fish. Oceanogr., 17:4, 281-298. 


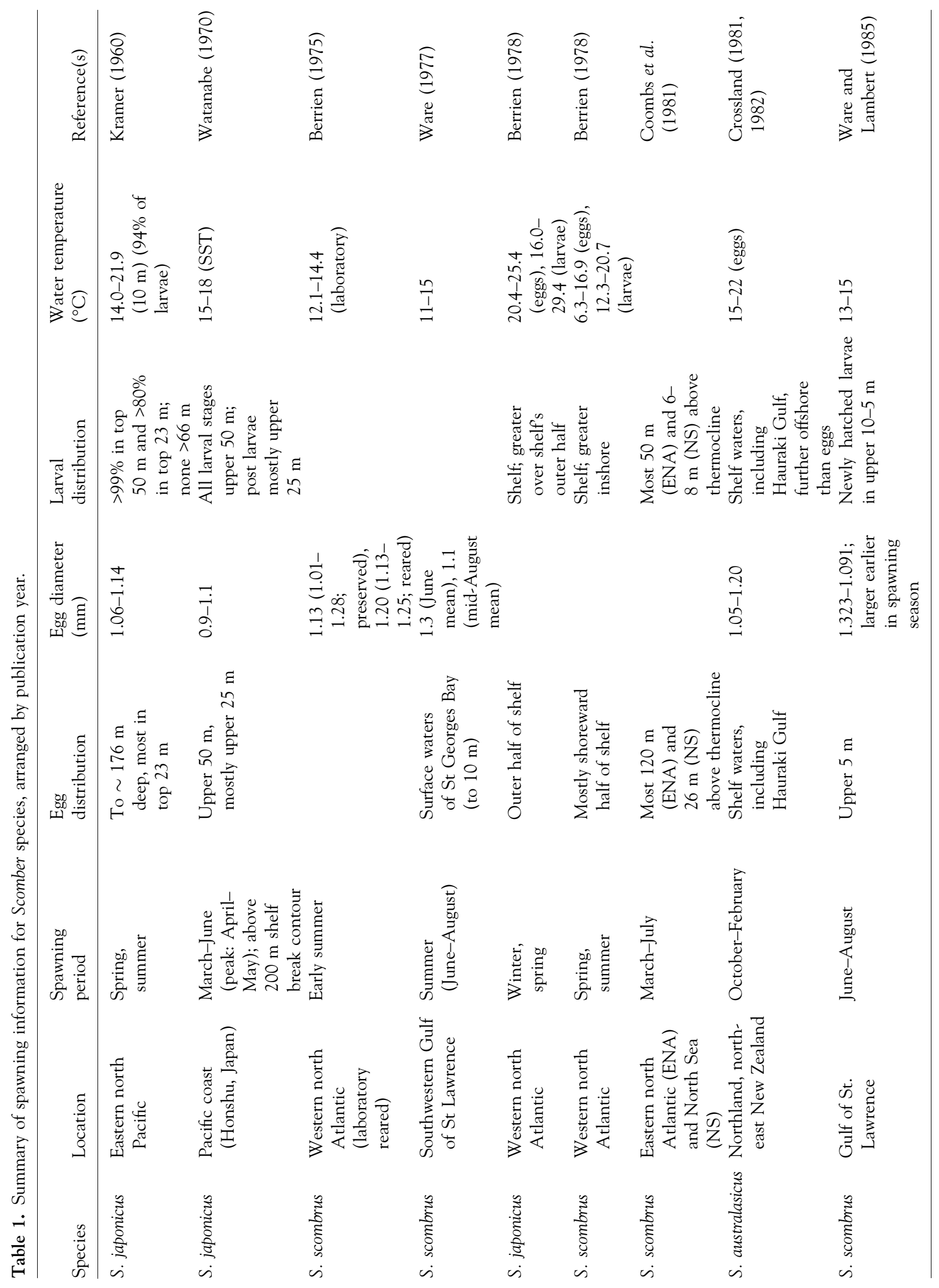

(C) 2008 The Authors, Fish. Oceanogr., 17:4, 281-298. 


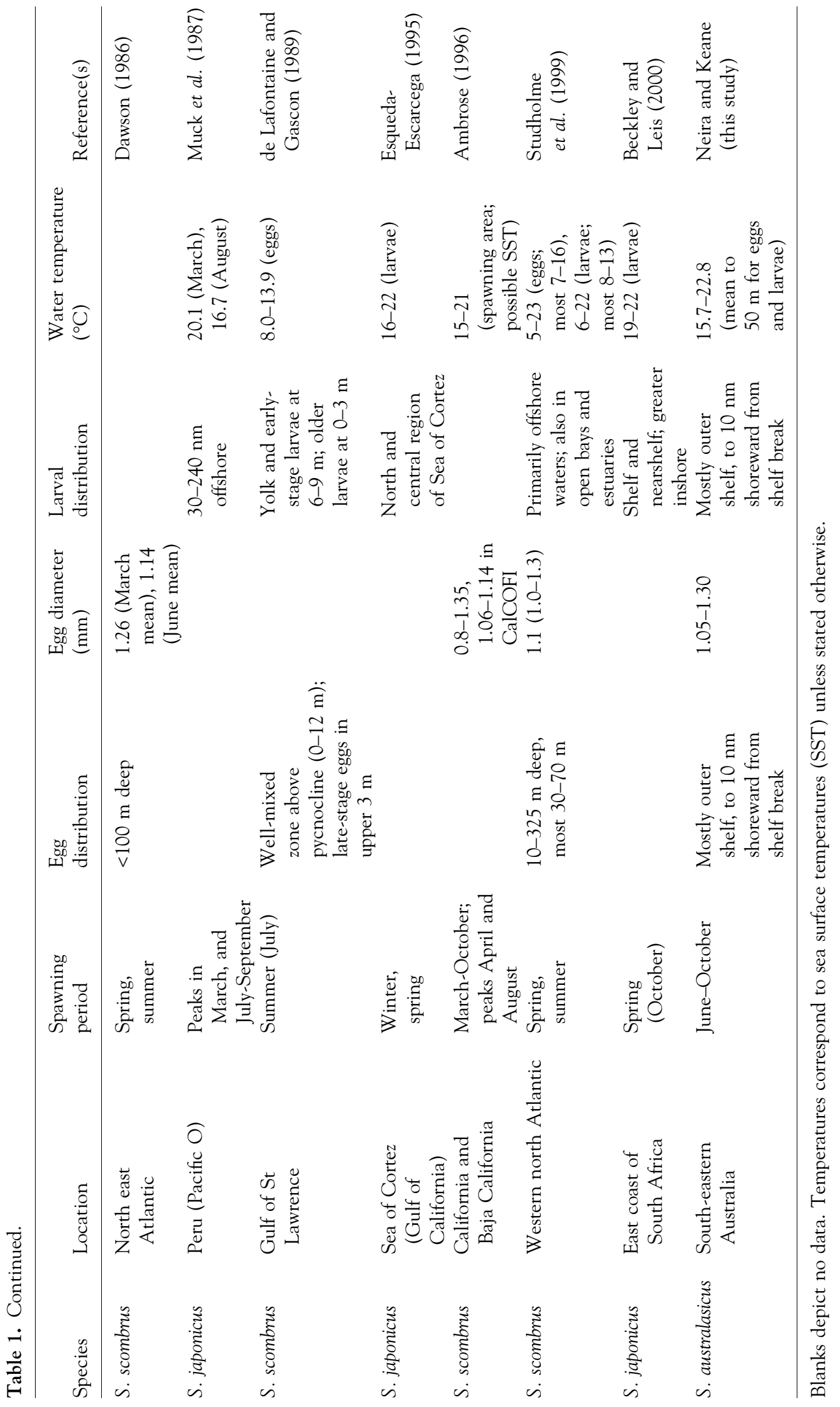

(c) 2008 The Authors, Fish. Oceanogr., 17:4, 281-298. 


\section{Sampling regime}

The sampling regime was identical during all surveys. Vertical plankton samples were collected using a bongo sampler consisting of 300 and $500 \mu \mathrm{m}$ mesh plankton nets, each $0.6 \mathrm{~m}$ in diameter and $3 \mathrm{~m}$ long. A General Oceanic flowmeter was attached to the mouth of each net to estimate the volume of water filtered $\left(\mathrm{m}^{3}\right)$. The sampler was enclosed within a purpose-built, weighted stainless steel frame to protect the nets and facilitate vertical drops, and fitted with a Scanmar depth sensor to regulate sampling depth. At each station the sampler was deployed from the stern of the vessel and lowered vertically to within $\sim 5 \mathrm{~m}$ of the seabed in waters $<200 \mathrm{~m}$, or to a maximum of $200 \mathrm{~m}$ to cover the entire water column above the shelf. The sampler was brought back on board soon after reaching the desired depth, both nets thoroughly washed, and plankton samples from the two hard codends combined and fixed immediately in $98 \%$ ethanol; a few samples were also fixed in 10\% formaldehyde-seawater. All fish eggs and larvae were sorted under a dissecting stereomicroscope, and stored in $98 \%$ ethanol.

\section{Identification of eggs and larvae}

Late-stage eggs of blue mackerel were initially identified using a combination of characters described for the eggs of S. japonicus and S. scombrus (Kramer, 1960; Berrien, 1975; Fritzsche, 1978; Baker and Collette, 1998; Mendiola et al., 2007), as well as detailed examination of a sample of formalin-fixed S. japonicus eggs from the north-eastern Pacific from the collection housed at the NOAA's South-west Fisheries Science Center (La Jolla, CA, USA). Early/late-stage eggs identified as S. australasicus $(n=50)$ as well as morphologically similar eggs from other fishes $(n=29)$ were subsequently subjected to current mtDNA barcoding techniques to verify species identity. The methodology (Evans et al., 1998) consisted of high throughput DNA extracting from individual eggs, amplification using polymerase chain reaction (PCR), and the sequencing of the cytochrome $b$ (cytb), and the $12 \mathrm{~s}$ and $16 \mathrm{~s}$ rRNA fragments of the mitochondrial genome, as well as the $655 \mathrm{bp}$ region of the proteincoding cytochrome oxidase subunit I gene (COX1). The COX1 gene marker was chosen for this study since it constitutes the marker being used in the Fish Barcode of Life (FISH-BOL) database being developed for fishes worldwide (Hebert et al., 2003; Ward et al., 2005; F.J. Neira, unpublished data). Fragments were amplified and analysed in either forward, reverse or both directions, and the sequences compared to the
Figure 1. Stations sampled along shelf waters of southeastern Australia (southern Qld to southern NSW) for eggs and larvae of blue mackerel during surveys in October 2002, October 2003 and July 2004.

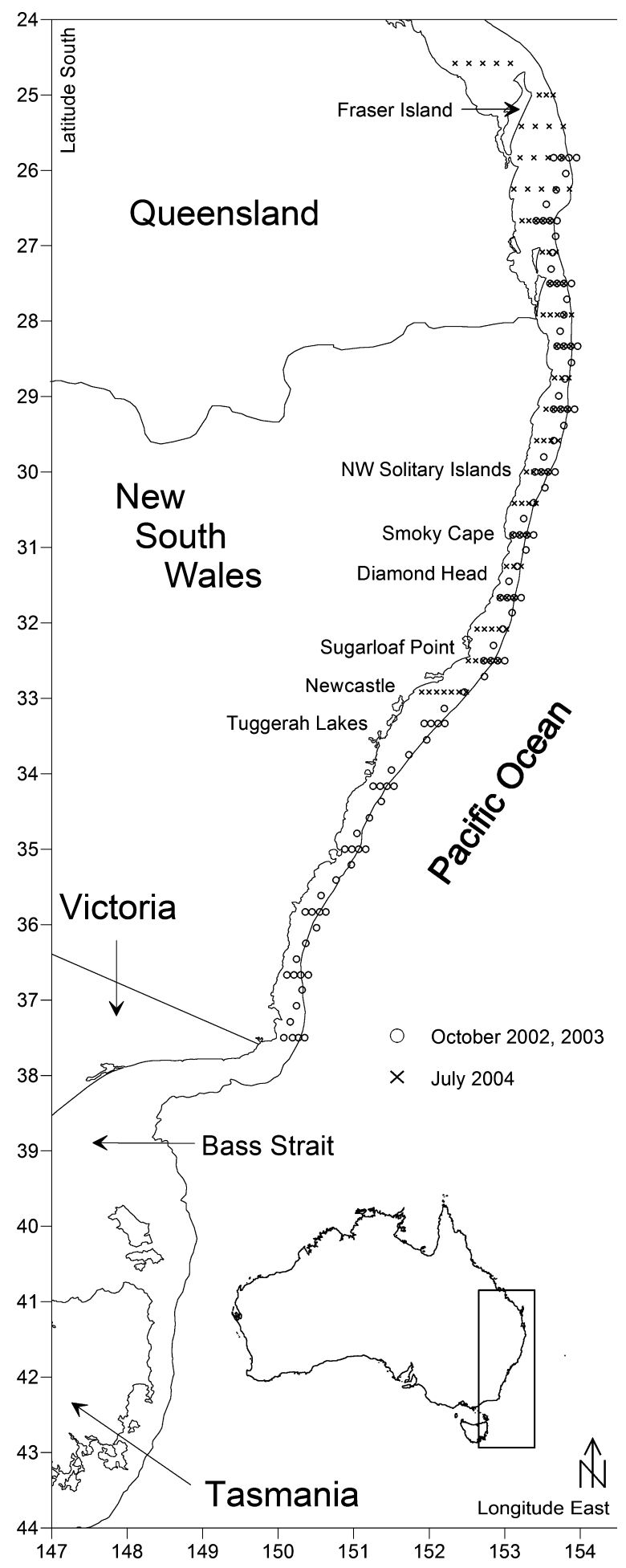


Table 2. Details of ichthyoplankton surveys conducted along shelf waters of south-eastern Australia in October 2002 and 2003 , and July 2004 to collect blue mackerel eggs and larvae.

\begin{tabular}{|c|c|c|c|c|c|c|}
\hline $\begin{array}{l}\text { Survey date } \\
\text { (season) }\end{array}$ & Shelf region sampled & $\begin{array}{l}\text { Range } \\
\text { Latitude o S }\end{array}$ & $\begin{array}{l}\text { Distance } \\
(\mathrm{nm})\end{array}$ & Stations & Samples & $\begin{array}{l}\text { Positive } \\
\text { stations (\%) }\end{array}$ \\
\hline $\begin{array}{l}\text { 12-22 October } \\
2002 \text { (Sp) }\end{array}$ & Southern Qld - southern NSW & $25.8-37.5$ & 775 & 102 & 97 & $25(25.8)$ \\
\hline $\begin{array}{l}\text { 1-8 October } \\
2003(\mathrm{Sp})\end{array}$ & Southern Qld - southern NSW & $25.8-37.5$ & 775 & 75 & 74 & $29(39.2)$ \\
\hline $\begin{array}{l}\text { 19-28 July } \\
2004 \text { (W) }\end{array}$ & Southern Qld - mid-NSW & $24.6-32.9$ & 450 & 85 & 85 & $45(52.9)$ \\
\hline
\end{tabular}

Along-shelf distance covered during each survey (nautical miles; nm) is approximate. NSW, New South Wales; Qld, Queensland; Sp, spring; W, winter.

GenBank nucleic acid public database (National Center for Biotechnology Information, NCBI) using the BLAST algorithm (http://www.ncbi.nlm.nih.gov/ BLAST; last accessed December 2006); COX1 sequences were also compared to FISH-BOL using the BoLD Identification System (http://www. barcodinglife.org/views/idrequest.php; last accessed December 2006). Eggs which returned a negative match with S. australasicus were removed from counts, and samples re-checked to eliminate possible contamination by non-blue mackerel eggs in final counts. Likewise, eggs visually identified as other fishes but which matched S. australasicus following genetic analyses, were returned to the samples and total numbers re-counted after re-examining samples.

Blue mackerel larvae were identified following Neira et al. (1998). Larvae were separated into preflexion, flexion and postflexion stages, with 'larva' being defined as the developmental stage between hatching and the attainment of full external meristic characters (e.g. fins), including the loss of temporary specializations to larval life.

\section{Environmental variables}

Temperature $\left({ }^{\circ} \mathrm{C}\right)$ and salinity data by depth $(\mathrm{m})$ were obtained simultaneously with each plankton sample using a Seabird Electronics SBE19 CTD (Conductivity-Temperature-Depth) profiler fitted to the bongo frame. Unless stated otherwise, mean temperatures and salinities provided correspond to means to a depth of $50 \mathrm{~m}$, while ranges correspond to $25 \%$ and $75 \%$ percentiles. Composite, high resolution sea-surface temperature (SST) images of south-eastern Australia (NOAA AVHRR satellite) were obtained for the survey periods from CSIRO Marine (Hobart). Images were selected from 5-day averages centred on the sampling days. A composite TS diagram was constructed from all surveys using mean temperatures and salinities of all sampled stations to $50 \mathrm{~m}$.

\section{Data analyses}

Total counts of eggs and larvae were standardized to surface area (abundance, numbers per $10 \mathrm{~m}^{2}$ ) based on water volume filtered and depth of net drop, and plotted by station for each survey using SURFER ${ }^{\circledR}$. Statistical analyses were performed using STATISTICA ${ }^{\circledR}$. Egg and larval abundances were compared statistically in terms of distance ( $\mathrm{nm}$ ) from and past the shelf break, following the classification of each station as either shoreward $(-10,-5 \mathrm{~nm})$, break $(0 \mathrm{~nm})$ or offshore $(5 \mathrm{~nm})$. Analyses included the area limited by the northern-most and southern-most positive stations, including embedded stations with no eggs (Table 2). Since the winter sampling design differed from that implemented during spring surveys, including a reduction in sampling area, data from the winter survey were analysed separately. Main effects ANOVA (unequal sample size) was performed to determine whether spring eggs and larval abundances differed significantly by distance $(n=4)$ and cruise $(n=2)$; all data were log-transformed $\left(\log _{10}[n+1]\right)$ to account for heterogeneity of variance following Cochran's test. When factors were found to be significant, the Bonferroni procedure was applied to ascertain which levels were different (Quinn and Keough, 2002). All percentage values are based on abundances unless stated otherwise.

Quotient analyses (van der Lingen et al., 2001; Checkley, 2005; Ibaibarriaga et al., 2007) were performed on egg abundance data across all three surveys combined to describe selection of spawning habitat in terms of distance from the shelf break $(\mathrm{nm})$ and depth $(\mathrm{m})$ of water column, and water temperature $\left({ }^{\circ} \mathrm{C}\right)$. For the latter we used mean temperatures of each station to a depth of $50 \mathrm{~m}$, based on information of the spawning mode depth of S. japonicus and S. scomber (Kramer, 1960; Ware, 1977; Dawson, 1986; de Lafontaine and Gascon, 1989; Studholme et al., 1999; Table 1). For these analyses, egg abundances (eggs per $10 \mathrm{~m}^{2}$ ) within 
each $5 \mathrm{~nm}$ stretch, $25 \mathrm{~m}$ depth interval and $0.5^{\circ} \mathrm{C}$ classes were expressed as a percentage of total abundance, divided by the percentage frequency of occurrence under each distance, depth interval and temperature, respectively, and plotted. Quotients $>1$ indicate positive spawning location, i.e. favoured distance, water depth and temperature range. Identical analyses were performed on larval abundance data. A composite bubble plot of egg and larval abundances over temperatures and salinities (means to $50 \mathrm{~m}$ ) was constructed from all surveys to ascertain the specific temperature/salinity range where eggs and larvae occurred.

Water masses present in the areas surveyed were identified from a combination of SST images and nonmetric multi-dimensional scaling (nMDS) ordination plots of standardized temperature frequencies based on all CTD-measured values (refer to Keane and Neira, 2008, for details on PRIMER-based multivariate analyses). Bubble plots representing relative abundances of eggs and larvae of blue mackerel (ln-transformed) were superimposed over nMDS plots to highlight associations with the underlying water mass structure (Field et al., 1982).

\section{RESULTS}

\section{Egg identification}

Pelagic eggs of blue mackerel were identified by the following combination of features: (a) spherical, 1.05$1.30 \mathrm{~mm}$ in diameter; (b) smooth chorion; (c) small perivitelline space; (d) prominent, unsegmented yolk sac; (e) single oil globule, $0.26-0.31 \mathrm{~mm}$ in diameter, which becomes pigmented mid-stage in development, and that is posteriorly located in the yolk of late-stage eggs and yolk-sac larvae; and (f) embryo pigment consisting of a paired row of melanophores along the dorsal surface of trunk and tail, and no pigment over the nape region (Fig. 2).

Of the 50 early- to late-stage eggs visually identified as S. australasicus and for which PCR amplifications were successful, 49 (98\%) returned a positive match with the species when sequence gene fragments were compared to those in the GenBank and BoLD databases (37 with COX1, 8 with 16s, 4 for $c y t b$ and 1 with 12s). Eggs visually identified as other fishes matched a variety of taxa, including the triglids Lepidotrigla spp. and Chelidonichthys kumu, and the scombrid Auxis rochei.

\section{Oceanographic conditions}

Composite SST images of the eastern Australian shelf region around the survey days (Fig. 3) show the front of the south-flowing EAC extending to $\sim 30-35^{\circ} \mathrm{S}$,
Figure 2. Eggs of Scomber australasicus from northern New South Wales. (a) $1.20 \mathrm{~mm}$ diameter, mid-stage. (b) $1.25 \mathrm{~mm}$ diameter, prehatching. Photos by the authors (fixative: $98 \%$ ethanol).
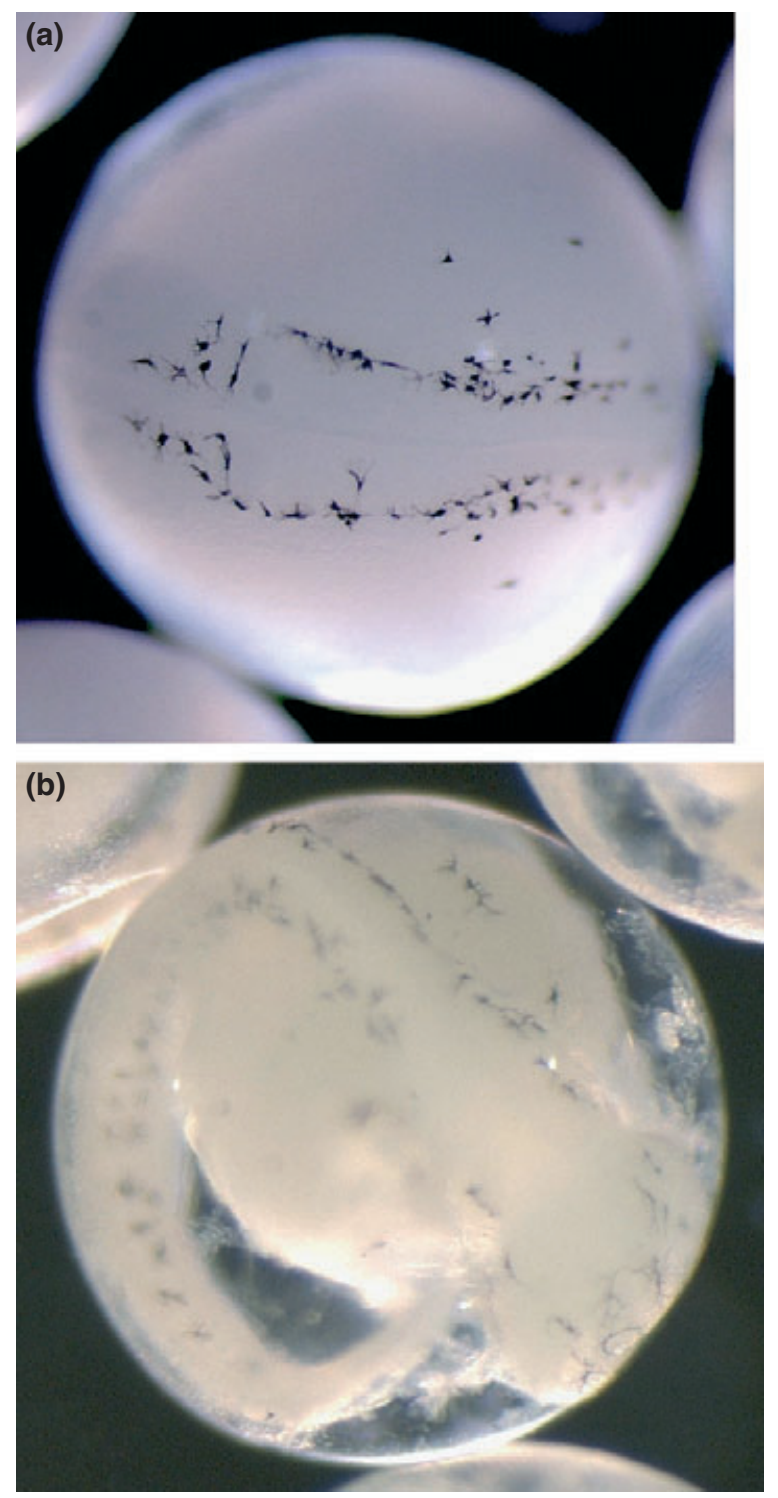

having reached $\sim 120 \mathrm{~nm}$ further south in October $2002\left(35^{\circ} \mathrm{S}\right)$ than in October $2003\left(33^{\circ} \mathrm{S}\right)$. Furthermore, the main EAC flow could be observed leaving the coast and deflecting eastwards off mid-NSW between $31.0^{\circ} \mathrm{S}$ (Smoky Cape) and $32.5^{\circ} \mathrm{S}$ (Sugarloaf $\mathrm{Pt}$ ) in October 2002 and 2003, forming a large anticyclonic eddy in October 2002 (Fig. 3).

Average CTD-measured SSTs between $25.8^{\circ} \mathrm{S}$ (Fraser Is.) and the southern EAC front in mid-NSW during the spring surveys were $19-23^{\circ} \mathrm{C}$, dropping to $15-18^{\circ} \mathrm{C}$ south of the EAC front. Sea surface 

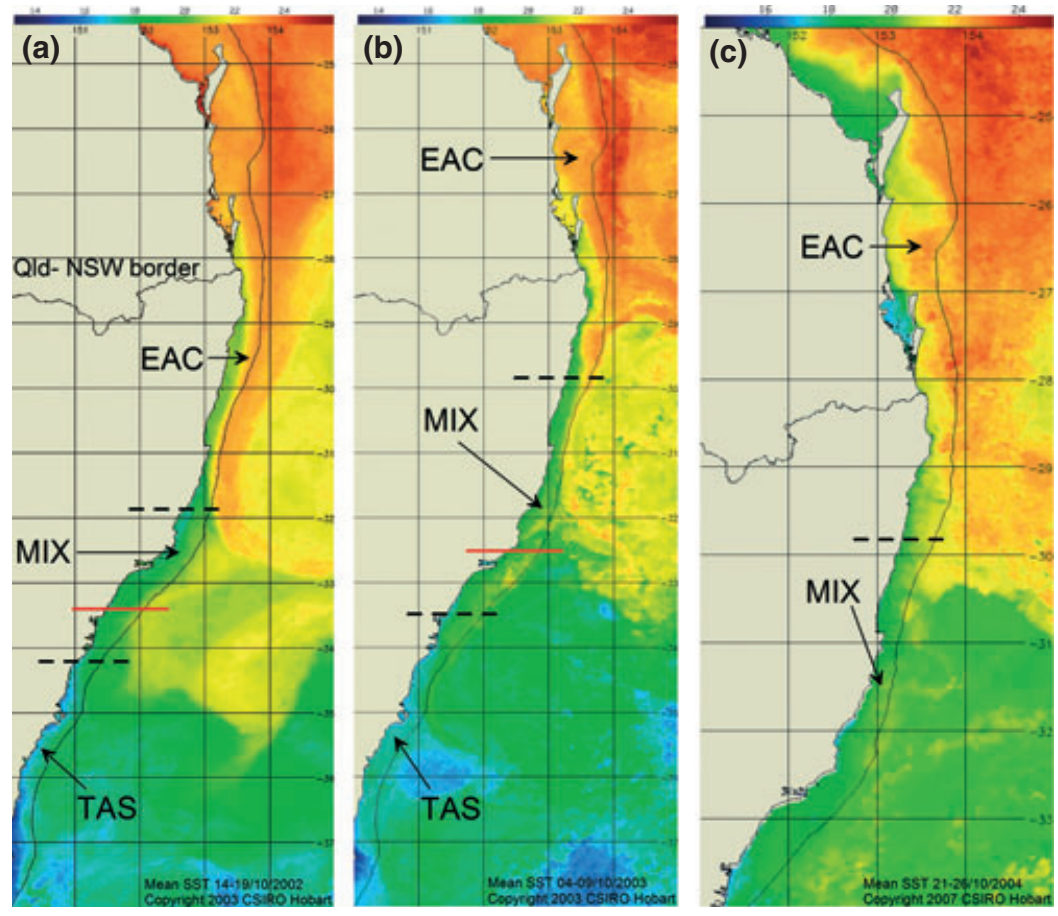

Figure 3. Composite SST images of south-eastern Australia in October 2002 (a), October 2003 (b) and July 2004 (c), showing approximate boundaries between the coastal body of the East Australian Current (EAC), and the mixed (MIX) and Tasman Sea (TAS) water masses (dashed lines) (refer to Keane and Neira, 2008, for details); note reduced southern extension of EAC in October 2003. Solid red lines in October 2002 and 2003 indicate southern distribution limits of blue mackerel eggs during each survey. Line along coastline corresponds to the $200 \mathrm{~m}$ shelf break contour. (Images provided by CSIRO Marine \& Atmospheric Research - Remote Sensing Facility).

temperatures obtained at the offshore-most stations of transects across the main EAC body off southern Qld during all positive surveys were $1.3-2.3^{\circ} \mathrm{C}$ warmer than those at the inshore-most stations of the same transects (Fig. 3).

Satellite images with superimposed surface ocean currents for selected days during the October surveys (not included; http://www.marine.csiro.au/remotesensing; last accessed December 2005) show the southwards advancing EAC $\left(0.6-0.8 \mathrm{~m} \mathrm{~s}^{-1}\right)$ forming a large, anticlockwise warm eddy that detaches from the coast off $31.0^{\circ} \mathrm{S}$. South-flowing inshore currents $\left(0.2-0.4 \mathrm{~m} \mathrm{~s}^{-1}\right)$ were also evident south of the EACdominated shelf region along mid-southern NSW.
Multivariate analyses of standardized water column temperature frequencies obtained in October 2002 and 2003 clearly distinguished three water masses in the survey area, namely EAC, mixed (herein termed MIX) and Tasman Sea (herein termed TAS) waters; identical analyses also distinguished EAC and MIX water in July 2004 (Fig. 3a-c; see Keane and Neira, 2008). The EAC-MIX and MIX-TAS interfaces were detected at about $31.8^{\circ} \mathrm{S}$ and $34.3^{\circ} \mathrm{S}$ in October 2002, and $29.9^{\circ} \mathrm{S}$ and $33.7^{\circ} \mathrm{S}$ in October 2003, respectively (Fig. 3a,b). The EAC-MIX front in July 2004 occurred at $\sim 29.8^{\circ} \mathrm{S}$, at a similar parallel to that in October 2003 (Fig. 3c). Latitudinal distinction between the three water masses was also clear in the

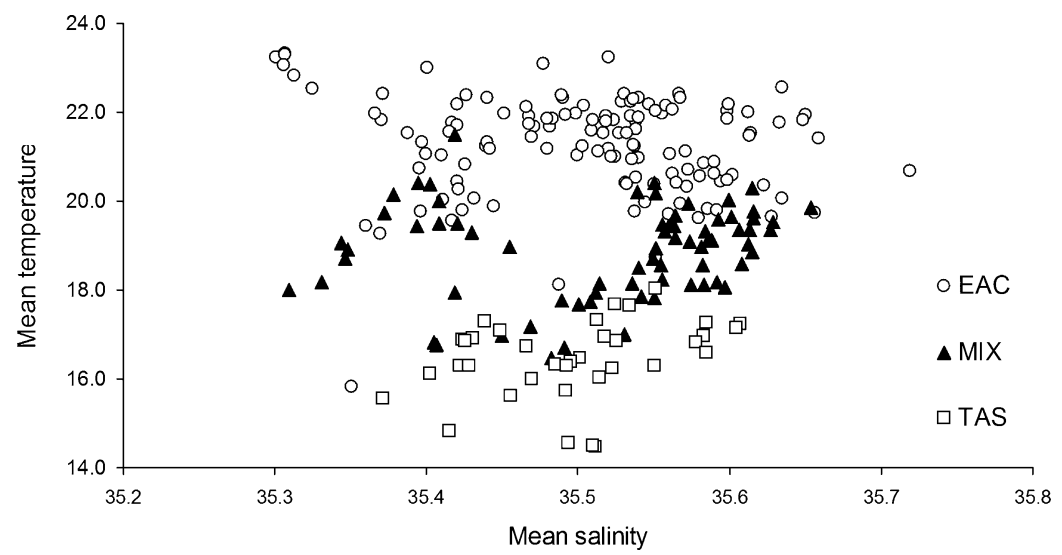

Figure 4. Composite temperature-salinity diagram showing the three main water masses identified along the continental shelf off south-eastern Australia during this study. Data for each station correspond to mean temperatures and salinities to $50 \mathrm{~m}$. EAC, East Australian Current; MIX, mixed; TAS, Tasman Sea water. 
Table 3. Temperature $\left({ }^{\circ} \mathrm{C}\right.$ ) and salinity characteristics (means to $50 \mathrm{~m}, \mathrm{CV}$, and ranges) of water masses identified during surveys along shelf waters of south-eastern Australia in October 2002 and 2003 (combined data), and July 2004.

\begin{tabular}{|c|c|c|c|c|c|c|}
\hline & \multicolumn{2}{|l|}{ EAC } & \multicolumn{2}{|l|}{ MIX } & \multicolumn{2}{|l|}{ TAS } \\
\hline & Mean (CV) & Range & Mean (CV) & Range & Mean (CV) & Range \\
\hline \multicolumn{7}{|l|}{ Temperature } \\
\hline October 2002, 2003 & $21.39(6.5)$ & $20.58-22.30$ & $19.09(6.3)$ & $18.51-19.83$ & $16.45(5.6)$ & $15.99-17.06$ \\
\hline July 2004 & $21.14(3.3)$ & $20.58-21.81$ & $18.70(5.8)$ & $18.13-19.45$ & & \\
\hline \multicolumn{7}{|l|}{ Salinity } \\
\hline October 2002, 2003 & $35.49(0.3)$ & $35.41-35.57$ & $35.49(1.5)$ & $35.40-35.60$ & $35.50(0.2)$ & $35.44-35.55$ \\
\hline July 2004 & $35.53(0.4)$ & $35.50-35.57$ & $35.55(0.5)$ & $35.53-35.59$ & & \\
\hline
\end{tabular}

EAC, East Australian Current; MIX, mixed; TAS, Tasman Sea water.

composite TS diagram of mean temperature-salinity data across surveys, with MIX water between the warmer EAC water to the north and cooler TAS water to the south (Fig. 4). Mean temperatures/salinities of each water mass were $21.3^{\circ} \mathrm{C} / 34.24$ (EAC), $18.9^{\circ} \mathrm{C} / 35.18$ (MIX) and $16.5^{\circ} \mathrm{C} / 35.50$ (TAS water), with variability being consistently lower for salinities $(\mathrm{CV}=0.2-1.5 \%)$ than for temperatures $(\mathrm{CV}=3.3-$ $6.3 \%$ ) across all surveys (Table 3 ).

Abundance and distribution of eggs and larvae

A total of 2971 eggs and 727 larvae of blue mackerel were caught along shelf waters between $25.0^{\circ} \mathrm{S}$ (southern Qld) and $34.6^{\circ} \mathrm{S}$ (mid-NSW) during the October 2002 and 2003, and July 2004 surveys (Figs 5 and 6; Table 4). The northern and southern limits of egg distribution in October $2002\left(27.1-33.5^{\circ} \mathrm{S}\right)$ were located 66 and $60 \mathrm{~nm}$ further south than in October $2003\left(26.0-32.5^{\circ} \mathrm{S}\right)$, respectively. The same was true for larvae except that their southern limits in both surveys lay 44-60 nm further south from the southern egg limits (Figs 5 and 6). Except for the region off $24.6^{\circ} \mathrm{S}$ in southern Qld, eggs in July 2004 occurred along most shelf waters while larvae were patchier compared to the spring surveys (Fig. 6).

Peak egg abundances (eggs per $10 \mathrm{~m}^{2}$ ) in October 2002 (1214), October 2003 (7390) and July 2004 (1775) were obtained from $31.7^{\circ} \mathrm{S}$ (Diamond $\mathrm{Hd}$ ) to $32.9^{\circ} \mathrm{S}$ (Newcastle) in northern NSW, at stations 0 to $-10 \mathrm{~nm}$ (Table 4; Figs 5 and 6). Collectively, 96.5\% of eggs collected across three surveys came from $0,-5$ and $-10 \mathrm{~nm}$ stations. Abundances differed significantly between spring surveys $\left(F_{1,94}=6.29 ; P<0.05\right)$ and distances from the break $\left(F_{3,94}=5.52 ; P<0.01\right)$, with eggs being significantly more abundant in October 2003, and at -5 and $-10 \mathrm{~nm}$. The latter reflects the fact that $88-96 \%$ of eggs during spring came from these stations, whereas $<12 \%$ came from 0 and $5 \mathrm{~nm}$ offshore. About $90 \%$ of eggs in the winter survey were caught at 0 to $-10 \mathrm{~nm}$, with eggs becoming comparatively less abundant beyond $-10 \mathrm{~nm}$. Quotients of egg abundance across all three surveys peaked sharply at stations $10 \mathrm{~nm}$ inshore from the break, before gradually declining towards stations $5 \mathrm{~nm}$ offshore from the break (Fig. 7a). In terms of water column depth, egg abundance quotients peaked sharply at stations sampled within the $100-125 \mathrm{~m}$ depth interval (Fig. 7b).

Peak larval abundances (larvae per $10 \mathrm{~m}^{2}$ ) during October 2002 (437), October 2003 (1172) and July 2004 (461) were obtained between 30.0ㅇ S (NW Solitary Islands) and $33.3^{\circ} \mathrm{S}$ (Tuggerah Lakes) in northern NSW, at stations 0 and $-5 \mathrm{~nm}$ (Table 4; Figs 5 and 6). Collectively, $\sim 95 \%$ of all larvae collected across the positive surveys came from $0,-5$ and $10 \mathrm{~nm}$ stations. Nearly $94 \%$ of larvae in October 2002 came from -5 and $-10 \mathrm{~nm}$ stations, whereas $\sim 6 \%$ came from 0 to $5 \mathrm{~nm}$ offshore. In contrast, $45 \%$ of larvae in October 2003 were caught at -5 and $-10 \mathrm{~nm}$, while $50 \%$ came from break stations (Fig. 5). Unlike eggs, no significant differences in larval abundances were detected between spring surveys or among distances from the break $(P>0.05)$. As with eggs, almost $94 \%$ of larvae caught in the winter survey came from 0 to $-10 \mathrm{~nm}$ stations, with larvae becoming noticeably less abundant past $-10 \mathrm{~nm}$ (shorewards). Larval abundance quotients peaked sharply at stations located at the shelf break, and at stations sampled within the 150-175 m depth interval (Fig. 7a,b). Nearly 94\% of all blue mackerel larvae caught during the spring $(n=491)$ and winter $(n=180)$ surveys were at the preflexion stage, with the remaining $6 \%$ comprising flexion $(n=39)$ and postflexion $(n=17)$ larvae (Table 5). 

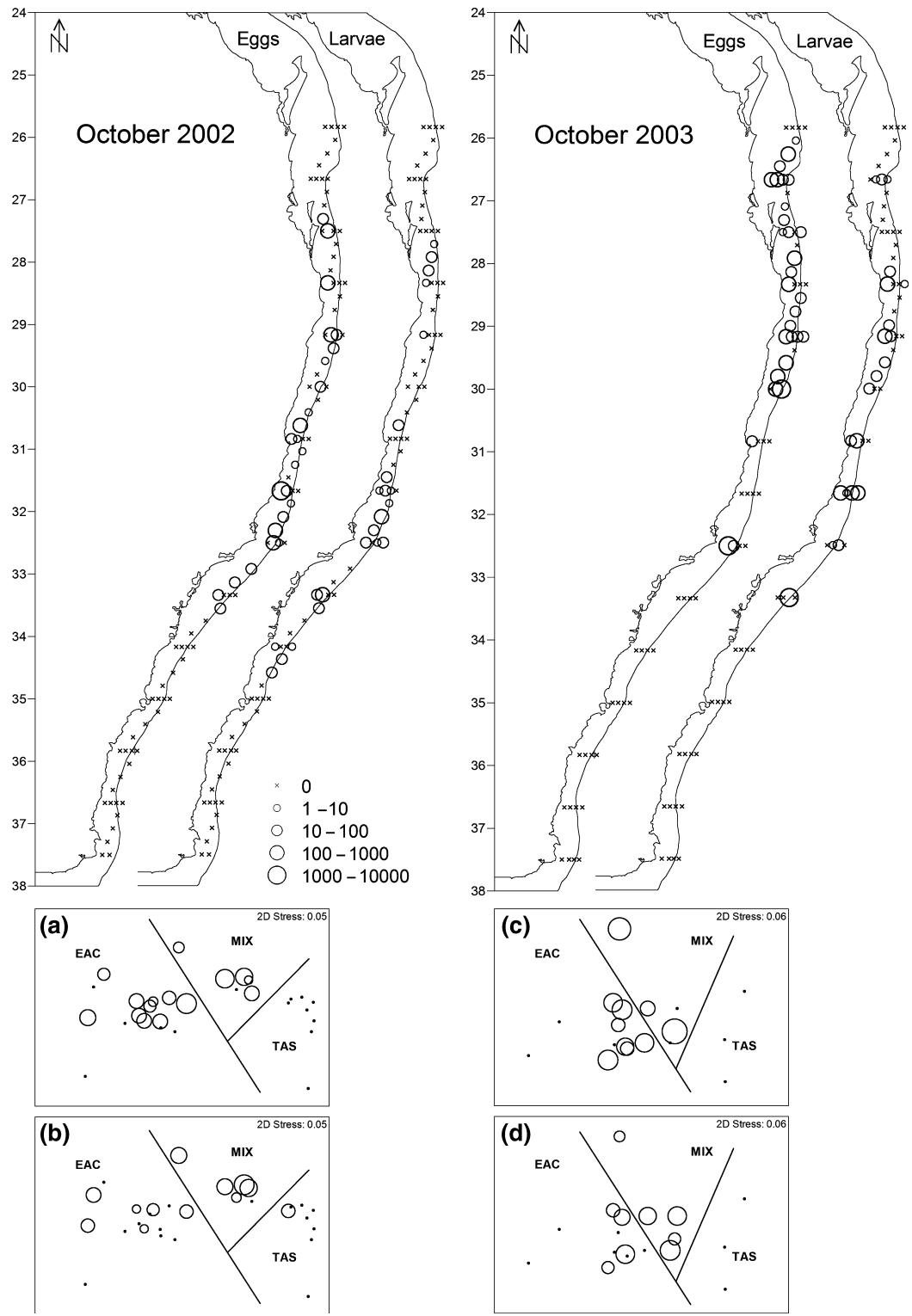

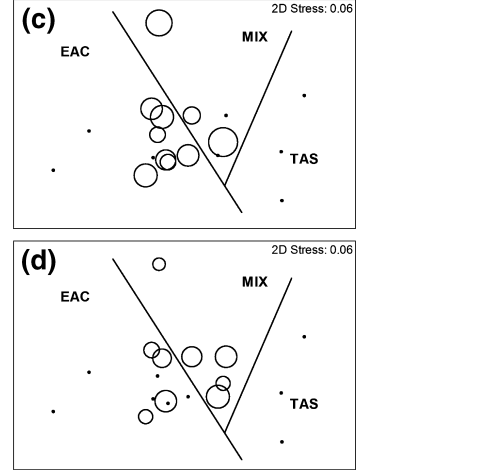

Figure 5. Distribution of eggs and larvae of blue mackerel (numbers per $10 \mathrm{~m}^{2}$ ) along south-eastern Australia in October 2002 (top left) and 2003 (top right). Abundance scale applies both to eggs and larvae; only latitude $S$ is provided (refer to Fig. 1 for localities and longitude). Solid line along coastline depicts the $200 \mathrm{~m}$ shelf break contour. Bottom plots correspond to non-metric MDS ordination of transects from standardized temperature frequency matrices, with superimposed circles representing relative abundances of blue mackerel eggs ( $\mathrm{a}$, b) and larvae (c, d) in October 2002 (left) and 2003 (right); lines denote boundaries between the East Australian Current (EAC), and mixed (MIX) and Tasman Sea (TAS) water masses.
Association with environmental variables and water masses

Most blue mackerel eggs and larvae caught during this study originated from stations where mean temperatures and salinities were $18-21^{\circ} \mathrm{C}$ and $35.35-$ 35.60, respectively, with abundances declining rapidly $<17^{\circ} \mathrm{C}$ and $>23^{\circ} \mathrm{C}$ (Fig. 8 ); full ranges of mean temperatures of positive stations with abundances of $\geq 10$ eggs and/or larvae were $15.8-22.8^{\circ} \mathrm{C}$ and $17.0-21.9^{\circ} \mathrm{C}$, respectively. The egg abundance quotient for the three surveys combined was bi-modal, with a clear peak at $15.5^{\circ} \mathrm{C}$ associated with the large egg catches obtained off $31.6^{\circ} \mathrm{S}$ (Diamond $\mathrm{Hd}$ ) during October 2002 (Fig. 5), and an overall larger peak at 19.0-20.0; the larval abundance quotient showed a slightly broader peak between 17.5 and $19.5^{\circ} \mathrm{C}$ (Fig. 7c).

Combined nMDS ordination of transects from temperature frequency matrices and egg/larval abundance plots showed that all blue mackerel eggs during the surveys occurred within EAC and MIX waters, and that none came from TAS waters (Figs 5a,c, 6a and 9). Similarly, larvae were almost exclusively associated with EAC and MIX waters (Figs 5b,d and 6b). Egg abundances averaged $>150$ eggs per $10 \mathrm{~m}^{2}$ along latitudes associated mostly with MIX water both in October $2002\left(31.5-32.5^{\circ} \mathrm{S}\right)$ and October 2003 (30.0$\left.32.5^{\circ} \mathrm{S}\right)$, as well as latitudes located at the EAC-MIX water interface (Fig. 9).

(C) 2008 The Authors, Fish. Oceanogr., 17:4, 281-298. 

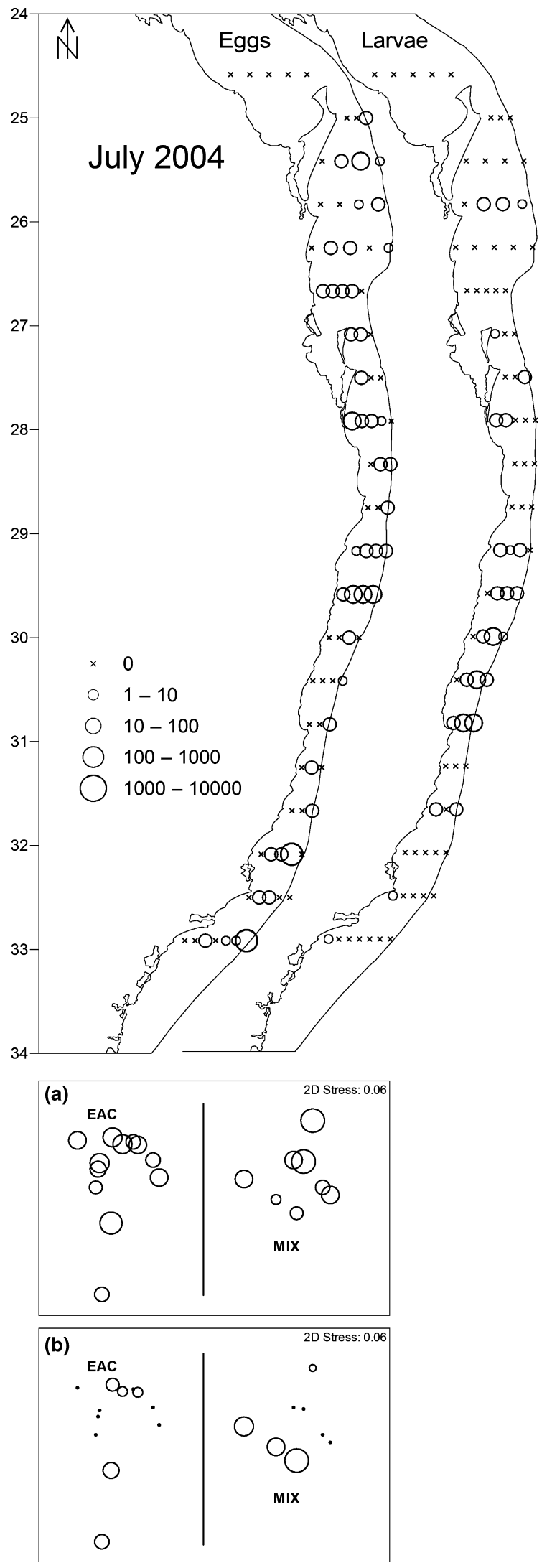

Figure 6. Distribution of eggs and larvae of blue mackerel (numbers per $10 \mathrm{~m}^{2}$ ) along south-eastern Australia in July 2004 (top). Abundance scale applies both to eggs and larvae; only latitude $S$ is provided (refer to Fig. 1 for localities and longitude). Solid line along coastline depicts the $200 \mathrm{~m}$ shelf break contour. Bottom plots correspond to non-metric MDS ordination of transects from standardized temperature frequency matrices, with superimposed circles representing relative abundances of blue mackerel eggs (a) and larvae (b) in July 2004; lines denote boundaries between the East Australian Current (EAC) and mixed (MIX) water.

\section{DISCUSSION}

Eggs and larvae

This constitutes the first ecological study to examine the distribution of eggs and larvae of blue mackerel (Scomber australasicus) in south-eastern Australia, and the first to employ molecular techniques to confirm the identity of their eggs. Since there were no detailed published descriptions of the pelagic eggs of this scombrid, except for a brief account of late-stage eggs from northern New Zealand (Crossland, 1981), we initially relied on a series of key morphological characters shared by the eggs of S. japonicus and S. scomber to visually identify blue mackerel eggs (Kramer, 1960; Berrien, 1975; Fritzsche, 1978; Mendiola et al., 2007). The subsequent application of mitochondrial DNA (mtDNA) to ethanol-preserved eggs identified as blue mackerel returned an identification accuracy of $98 \%$, which falls within the likely outcome of comparable molecular assays on fish eggs (e.g. Taylor et al., 2002). Re-checking all egg samples following this outcome helped to eliminate the likely contamination of impostor eggs, thus ensuring that all egg data reported herein were blue mackerel. While developing a species-specific genetic assay to simultaneously test a greater number of eggs was beyond the scope of this study, it may be worthwhile in future work with blue mackerel eggs, particularly to separate morphologically similar pelagic eggs from co-occurring taxa (Taylor et al., 2002). Genetic-based identification protocols are increasingly being applied in fish studies (Shao et al., 2001, 2002; Fox et al., 2005; Garcia-Vazquez et al., 2006; Pegg et al., 2006; Neira et al., 2008), especially with the growing database of the current world's DNA barcoding project (Hebert et al., 2003; Ward et al., 2005).

Based on literature accounts (see Table 1), as well as examination of formalin-fixed S. japonicus eggs from the north-eastern Pacific, wild eggs of S. australasicus appear to be nearly indistinguishable from those of the 
Table 4. Summary statistics of blue mackerel eggs and larvae caught during positive surveys along shelf waters of south-eastern Australia in October 2002 and 2003, and July 2004.

\begin{tabular}{|c|c|c|c|c|c|c|c|c|}
\hline Survey date & $\begin{array}{l}\text { Total } \\
\text { number }\end{array}$ & $\begin{array}{l}\text { Greatest } \\
\text { abundance } \\
\left(\text { nos per } 10 \mathrm{~m}^{2}\right)\end{array}$ & $\begin{array}{l}\text { Transect } \\
\text { (station) }\end{array}$ & $\begin{array}{l}\text { Latitude } \\
\left({ }^{\circ} \mathrm{S}\right)\end{array}$ & $\begin{array}{l}\text { Distance } \\
\text { from shelf } \\
\text { break }(\mathrm{nm})\end{array}$ & Depth (m) & Temp $\left({ }^{\circ} \mathrm{C}\right)$ & Sal \\
\hline \multicolumn{9}{|l|}{ Eggs } \\
\hline $12-20$ Oct 2002 & 491 & 1214 & $8(1)$ & 31.7 & -10 & 65 & 15.84 & 35.35 \\
\hline 1-7 Oct 2003 & 1641 & 7390 & $9(1)$ & 32.5 & -10 & 115 & 20.37 & 35.40 \\
\hline 20-27 Jul 2004 & 839 & 1775 & $21(7)$ & 32.9 & 0 & 138 & 19.37 & 35.06 \\
\hline \multicolumn{9}{|l|}{ Larvae } \\
\hline $12-20$ Oct 2002 & 197 & 437 [94] & $8-9(2)$ & 32.8 & -3.5 & 125 & 17.94 & 35.51 \\
\hline 1-7 Oct 2003 & 342 & 1172 [100] & $10(3)$ & 33.3 & 0 & 170 & 19.51 & 35.42 \\
\hline 20-27 Jul 2004 & 188 & $461[100]$ & $14(3)$ & 30.0 & -5 & 245 & 20.21 & 34.91 \\
\hline
\end{tabular}

Totals correspond to counts (raw numbers) across entire survey. Greatest egg and larval abundances (numbers per $10 \mathrm{~m}^{2}$ ) obtained during each survey are provided, together with transect (station), latitude $\left({ }^{\circ} \mathrm{S}\right)$ and distance shoreward from the shelf break $(\mathrm{nm})$ where these were recorded $(0 \mathrm{~nm}=$ break $)$; values next to peak larval abundances correspond to percentages [\%] of larvae at the preflexion stage (derived from standardized abundances). Depth $(\mathrm{m})$ refers to depth of station; temperatures (temp) and salinities (sal) correspond to means at each station to $50 \mathrm{~m}$.

former mackerel and, to great extent, from S. scomber. Collectively, Scomber eggs are spherical, have a smooth chorion and a prominent, unsegmented yolk, and are $0.80-1.35 \mathrm{~mm}$ in diameter $(1.05-1.30 \mathrm{~mm}$ in blue mackerel). They also possess a single, $0.22-0.38 \mathrm{~mm}$ diameter oil globule $(0.26-0.31 \mathrm{~mm}$ in blue mackerel) that lies off-centre from the animal axis early in development and posteriorly in the yolk of mid- to latestage eggs, and which becomes pigmented after the closure of the blastopore (Kramer, 1960; Berrien, 1975; Fritzsche, 1978; Crossland, 1981; Ambrose, 1996; Mendiola et al., 2007). The morphological similarities amongst these eggs extend also to the shape and pigment pattern of late-stage embryos, particularly the flat, enlarged nape region, and the paired row of melanophores along the embryo's dorsal surface from head to tail. Moreover, as with S. japonicus, mid/late-stage S. australasicus eggs also exhibit several yolk melanophores compared to at most two in S. scomber eggs. Thus, it appears that the amount of yolk pigment may be the only visible difference between the australasicusjaponicus complex and S. scomber (Kramer, 1960; Berrien, 1975, 1978). Similar eggs found co-occurring with those of blue mackerel during this study and identified via mtDNA included those of Lepidotrigla spp. (Triglidae) and Auxis rochei (Scombridae).

As with eggs, larval blue mackerel are virtually identical to those of $S$. japonicus, particularly during the early stages (Ozawa, 1984; Neira et al., 1998). Besides general morphology, similarities encompass sequence of fin formation and pigment development, as well as changes in body proportions and posterior migration of the anus (Ozawa, 1984). The similarities between these mackerel species at the larval stage is not surprising, and may reflect the fact that main differences between the adults amount to only three internal morphological characters (Baker and Collette, 1998). By contrast, larval S. japonicus and S. scombrus differ in several aspects (Berrien, 1978).

\section{Spawning season and area}

Ichthyoplankton data collected during this study indicate that blue mackerel along south-eastern Australia spawn at least from winter through to spring (July-October), and that spawning during that period is confined to continental shelf waters between $25.0^{\circ} \mathrm{S}$ and $34.0^{\circ} \mathrm{S}$. The conclusion of a winter-spring spawning as far south as $34.0^{\circ} \mathrm{S}$ is based on the fact that no eggs occurred past $33.5^{\circ} \mathrm{S}$ during the spring surveys despite extensive sampling to $37.5^{\circ} \mathrm{S}$. Moreover, no spawning takes place in mid-summer between $34.7^{\circ} \mathrm{S}$ (southern NSW) and $41.7^{\circ} \mathrm{S}$ (mid-eastern Tasmania), as neither eggs nor larvae of blue mackerel were caught along this area during plankton surveys carried out in February 2003 and 2004 (F.J. Neira, unpublished data).

The spatio-temporal limits of spawning of blue mackerel in south-eastern Australia could also be inferred from the shelf distribution of larvae. For example, the fact that $94 \%$ of the larvae caught during this study were at the early preflexion stage, i.e. just after egg hatching ( 3.0-5.0 mm; Neira et al., 1998), is arguably indicative of a close proximity to spawning grounds. Furthermore, blue mackerel larvae have been 
Figure 7. Quotients of abundances of blue mackerel eggs and larvae (numbers per $10 \mathrm{~m}^{2}$ ) by (a) distance from shelf break (nm); (b) depth intervals $(\mathrm{m})$; and $(\mathrm{c})$ mean temperature $\left({ }^{\circ} \mathrm{C}\right)$, from combined data obtained across surveys along south-eastern Australia in October 2002, October 2003 and July 2004. Open bars correspond to percentage frequency of occurrences of each distance, depth interval and temperature shown along $x$-axis, and includes all stations. Distance ' -40 ' corresponds to $40 \mathrm{~nm}$ shoreward from the shelf break (' $O$ '); depth corresponds to seafloor depth of positive stations; temperature corresponds to mean values at each station to $50 \mathrm{~m}$. Quotient values $>1$ (broken lines) indicate positive habitat/temperature selection.
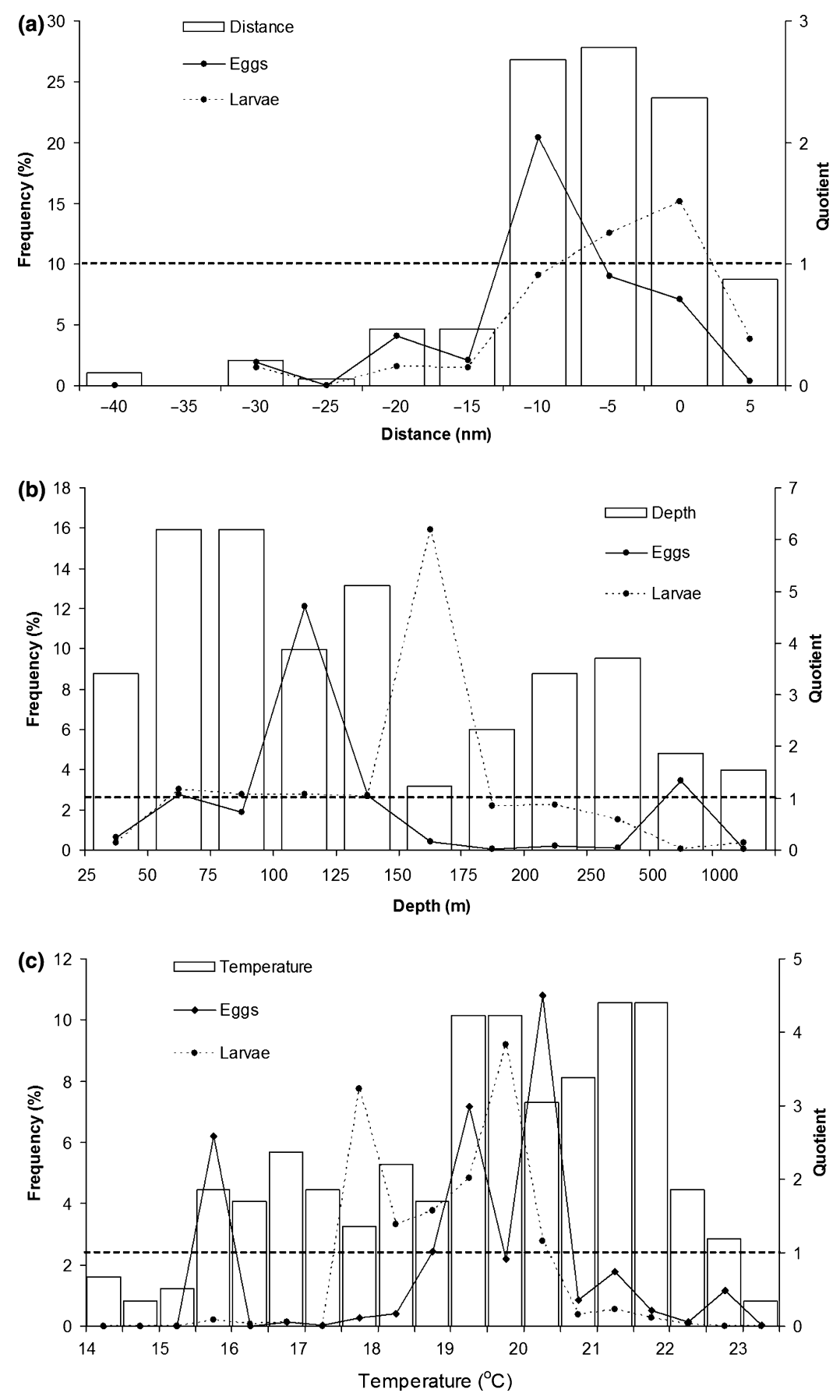

caught along the same south-eastern shelf Australian region (28.2-33.7 $)$ in July-August 1986 and August-September 1990-1992 (Dr A.G. Miskiewicz, unpublished data; Gray and Miskiewicz, 2000), and at the Tasman Front $\left(33.5^{\circ} ; 153.5^{\circ} \mathrm{E}\right)$ in September 2004 (T. Mullaney, unpublished data).

(C) 2008 The Authors, Fish. Oceanogr., 17:4, 281-298. 
Table 5. Total catch of blue mackerel larvae (split into developmental stages) during surveys conducted along shelf waters of south-eastern Australia in October 2002 and 2003, and July 2004.

\begin{tabular}{lllll}
\hline Survey & Preflexion & Flexion & Postflexion & Total \\
\hline $\begin{array}{l}12-20 \text { October } \\
2002\end{array}$ & $167(83.8)$ & $23(12.4)$ & $7(3.7)$ & 197 \\
$\begin{array}{l}\text { 1-7 October } \\
\text { 2003 }\end{array}$ & $324(95.4)$ & $12(3.4)$ & $6(1.2)$ & 342 \\
$\begin{array}{l}20-27 \text { July } \\
2004\end{array}$ & $180(97.2)$ & $4(1.5)$ & $4(1.3)$ & 188 \\
Total (\%) & $671(93.6)$ & $39(4.6)$ & $17(1.7)$ & 727 \\
\hline
\end{tabular}

Values in parentheses correspond to percentages (\%) of each developmental stage per survey derived from abundances (numbers per $10 \mathrm{~m}^{2}$ ).

Figure 8. Abundances of blue mackerel eggs and larvae (numbers per $10 \mathrm{~m}^{2}$ ) obtained at different combinations of temperatures and salinities (mean values at each station to $50 \mathrm{~m}$ ) during surveys along south-eastern Australia in October 2002 and October 2003, and July 2004 (most values grouped to the right of 35.5 along the salinity axis). Bubbles sizes are proportional to abundances.

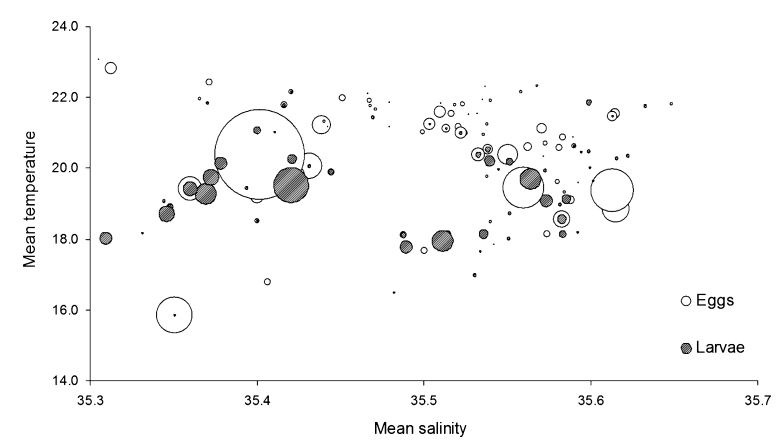

Although the limited information on spawning dynamics of $\mathrm{S}$. australasicus over its known distributional range (see Table 1) precludes a thorough comparison of our results with other populations of this mackerel, some parallels can be made with the congeneric S. japonicus. Thus, while the winter-spring spawning of S. australasicus in south-eastern Australia differs from that in spring-summer (October-February) reported for this species in north-east New Zealand (Crossland, 1981, 1982), it matches that known for S. japonicus in Pacific waters off Japan (Watanabe, 1970), the western North Atlantic (Berrien, 1978), the Pacific Ocean off Peru (Muck et al., 1987), the Sea of Cortez (Esqueda-Escarcega, 1995) and eastern South Africa (Beckley and Leis, 2000).

The spatial distribution of blue mackerel eggs indicate that spawning is generally confined to the outer shelf area including the shelf break. This observation is supported by quotient analyses on egg abundances pointing to the region within $10 \mathrm{~nm}$ shoreward from the shelf break as the preferred spawning area, in waters $100-125 \mathrm{~m}$ deep. Blue mackerel eggs have also been reported in New Zealand shelf waters, including Hauraki Gulf (Crossland, 1981, 1982), while S. japonicus eggs have been caught within the shelf's outer half (Berrien, 1978), and throughout the water column to depths of $176 \mathrm{~m}$ although most in the upper 25 m (Kramer, 1960; Watanabe, 1970). Like eggs, S. japonicus larvae have also been reported in large numbers predominantly along the outer shelf, in the upper 50-25 m (Kramer, 1960; Watanabe, 1970; Berrien, 1978; Beckley and Leis, 2000). A close association between spawning dynamics and bathymetry is not limited to scombrids, and has been described for other pelagic fishes, e.g. Atlantic menhaden (Checkley et al., 1999).

\section{Links with the East Australian Current}

Results of this ichthyoplankton-based study provide persuasive evidence of a close link between the spawning dynamics of blue mackerel during winterspring, and the EAC flow path along eastern Australia and subsequent interaction with shelf waters. This link is likely to include (1) suitably warm temperatures for spawning and development of the pelagic eggs and larvae; (2) a spawning area whose southern limit is restricted by the extent of the EAC incursion over the shelf; (3) spawning 'hotspots' in shelf areas where the eastward deflection of the main EAC flow triggers upwelling of nutrient-rich water; (4) the along-shelf southward advection of eggs and larvae; and (5) the across-shelf eastward advection of spawning products along the EAC deflection front. The EAC has already been indirectly linked to spawning patterns of some demersal and pelagic fishes in south-eastern Australia (e.g. Prince and Griffin, 2001; Ward et al., 2003).

The observation that blue mackerel favour relatively warm temperatures to spawn, at least during winter-spring in south-eastern Australia, is supported by the capture of eggs exclusively within EAC-MIX waters $\left(18.1-22.3^{\circ} \mathrm{C}\right)$, and matches the SST range of $15.0-22.0^{\circ} \mathrm{C}$ reported for blue mackerel eggs caught in New Zealand during spring-summer (Crossland, 1982). The selection of warm waters for spawning and egg development can be further demonstrated by the absence of eggs within TAS waters $\left(16.0-17.0^{\circ} \mathrm{C}\right)$, which in turn points to the MIX-TAS interface as a spawning barrier. In this context, it is perhaps relevant that eggs of S. japonicus fail to hatch at temperatures $<14^{\circ} \mathrm{C}$ (Hunter and Kimbrell, 1980), a fact which may 
Figure 9. Mean abundances of blue mackerel eggs (numbers per $10 \mathrm{~m}^{2}$ ) and mean temperatures to $50 \mathrm{~m}$ (solid line) along south-eastern Australia in October 2002 (top) and 2003 (bottom) pooled by 0.5 degree of latitude South; ns indicates region not sampled. Shaded rectangles depict approximate latitudinal boundaries and mean water temperature range of shelf components of the East Australian Current (EAC), and mixed (MIX) and Tasman Sea (TAS) water masses.

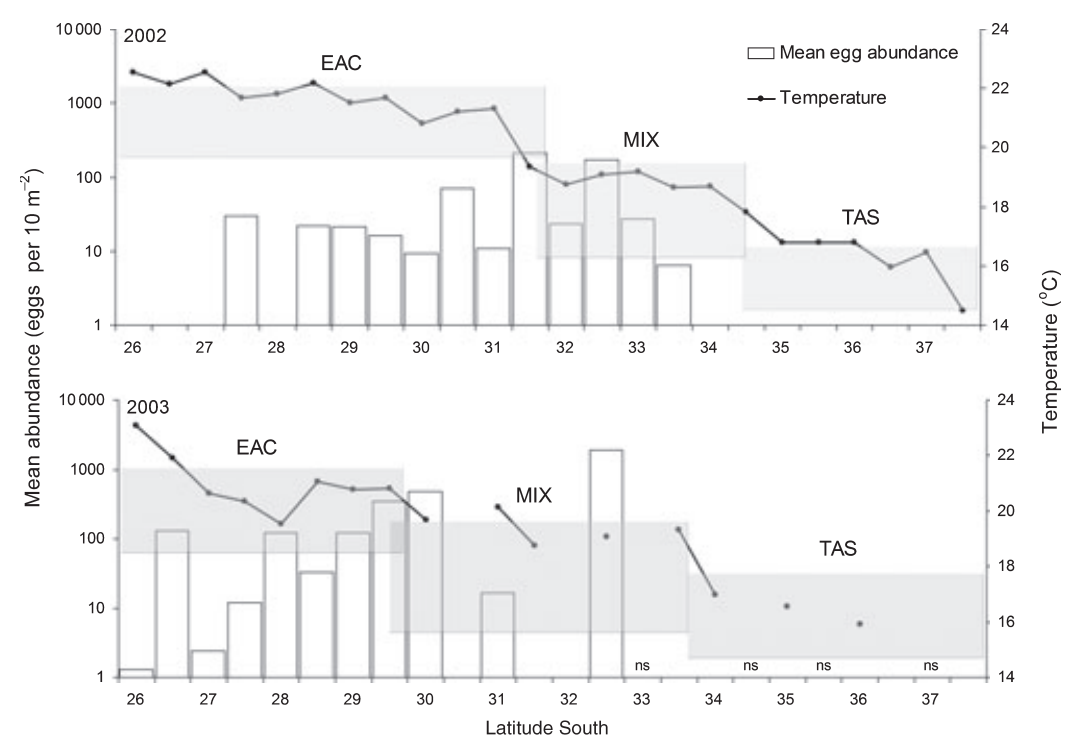

also apply to blue mackerel though equivalent egg rearing experiments would be needed to support such a proposition. While blue mackerel eggs during the spring surveys ceased to occur some 72-78 nm north of the MIX-TAS interface, the southern-most captures of blue mackerel larvae coincided almost exactly with the location of this interface, implying that this temperature front may also be acting as a barrier to the southward dispersal of larvae.

The NSW region where peak blue mackerel egg abundances were obtained during the spring surveys $\left(31.0-32.5^{\circ} \mathrm{S}\right)$ is normally where the main EAC flow leaves the shelf and deflects eastward (Nilsson and Cresswell, 1981). The occurrence of such high egg abundances within that region could well be linked to the fact that the EAC deflection triggers upwelling of cooler, nutrient-rich water leading to enhanced local productivity, particularly in winter-spring (Tranter et al., 1986; Hallegraeff and Jeffrey, 1993; Ridgway and Godfrey, 1997; Oke and Middleton, 2001). Upwelling would explain the high egg captures in $15.5^{\circ} \mathrm{C}$ water off Diamond Hd (31.6 $\mathrm{S}$ ) in October 2002, which in turn resulted in a bi-modal quotient egg analysis. Alternatively, it may be plausible that spawning products accumulate around those highly dynamic areas and are advected offshore (i.e. eastward) along the EAC deflection front. While our data cannot support of reject the latter hypothesis, a survey in September 2004 caught high numbers of blue mackerel larvae entrained within the Tasman Front, further offshore from the shelf break, with significantly fewer larvae just south of the Front (T. Mullaney, unpublished data). This finding implies that offshore larval transport, and also presumably eggs, is possible along the EAC deflection front at least during spring.

In summary, data on the distribution and temporal occurrence of eggs and larvae of blue mackerel obtained during this study, coupled with data on preferred spawning habitat, indicates that the population of blue mackerel found in south-eastern Australia spawns during winter-spring along the outer shelf region between southern Qld and northern NSW. Spawning does not, at least in winter-spring, take place within Tasman Sea waters south of the MIXTAS interface likely due to low temperatures $\left(\leq 17.0^{\circ} \mathrm{C}\right)$. In addition, the nature of our data does not support the hypothesis of a spawning migration north into southern Qld by neither part nor the entire southeastern blue mackerel stock at that time, despite northward movements being assumed for other pelagic fishes along western boundary current systems including the EAC (e.g. Beckley and Connell, 1996; Ward et al., 2003). Instead, the data strongly suggest that spawning dynamics of blue mackerel is closely linked to the EAC incursion both in terms of temperatures suitable for spawning and development of their eggs and larvae, as well as southward transport. The fact that eggs and larvae are also likely to be advected offshore (eastwards) along the EAC deflection front raises the possibility of the Tasman Front acting as an 
open-sea early nursery area, where entrained larvae may take advantage of conditions that favour high survival and growth rates. This hypothesis, however, along with information on what proportion of the stock spawns where and when, constitute key aspects yet to be closely examined before the DEPM is applied to this species anywhere in Australian waters.

\section{ACKNOWLEDGEMENTS}

The authors would like to sincerely thank all 26 staff and students who took turns to help during the surveys undertaken for the study, especially the skippers and crew from the Australian Maritime College (AMC) fisheries vessel Bluefin. Our gratitude also to Drs S. Applegate (CSIRO Marine, Hobart) and S. Davidson (Central Science Laboratory, University of Tasmania) for their extensive sequencing gene work to confirm the identity of blue mackerel eggs. Statistical advice was kindly provided by Dr M. Sporcic (CSIRO Marine, Hobart). Unpublished data on blue mackerel larvae were provided by Dr A.G. Miskiewicz (Wollongong Council, NSW) and Mr T. Mullaney (University of NSW). Authors would also like to acknowledge the valuable comments from Dr J.M. Lyle (Tasmanian Aquaculture and Fisheries Institute), as well as those of the journal's Editor-in-Chief (D.M. Checkley Jr) and two anonymous referees. Satellite images were provided by G. Smith (CSIRO Marine and Atmospheric Research Remote Sensing Facility). This study was funded by Fisheries Research and Development Corporation (Project 2001/61), with a significant in-kind contribution from the AMC; the Australia \& Pacific Science Foundation funded part of the molecular analyses.

\section{REFERENCES}

Ambrose, D.A.(1996) Scombridae: Mackerels and tunas. In: The Early Stages of Fishes in the California Current Region. H.G. Moser(ed.). Lawrence, KS: Allen Press, Inc. CalCOFI Atlas No. 33, pp. 1270-1285 .

Baker, E.A. and Collette, B.B. (1998) Mackerel from the northern Indian Ocean and the Red Sea are Scomber australasicus, not Scomber japonicus. Ichthyol. Res. 45:29-33.

Beckley, L.E. and Connell, A.D. (1996) Early life history of Pomatomus saltatrix off the east coast of South Africa. Mar. Freshw. Res. 47:319-322.

Beckley, L.E. and Leis, J.M. (2000) Occurrence of tuna mackerel larvae (Family: Scombridae) off the east coast of South Africa. Mar. Freshw. Res. 51:777-782.

Berrien, P.L. (1975) A description of Atlantic mackerel, Scomber scombrus, eggs and early larvae. Fish. Bull. 73:186-192.
Berrien, P.L. (1978) Eggs and larvae of Scomber scombrus and Scomber japonicus in continental shelf waters between Massachusetts and Florida. Fish. Bull. 76:95-115.

Bruce, D.D. and Bradford, R.W.(2002) A synthesis of existing data on the early life history of southern Australian finfish. Final Report FRCD 98/103. CSIRO Marine Research, $300 \mathrm{pp}$.

Checkley, D. Jr (2005) Temperature-salinity and quotient analyses of CUFES data from the California Current region. In: Report of a GLOBEC-SPACC Workshop on Characterizing and Comparing the Spawning Habitats of Small Pelagic Fish, pp. 14-15. C.D. van der Lingen, L. Castro, L. Drapeau \& D. Checkley Jr (eds). GLOBEC Report 21: xii, 33 pp.

Checkley, D.M. Jr, Ortner, P.B., Werner, F.E., Settle, L.E. and Cummings, S.R. (1999) Spawning habitat of the Atlantic menhaden in Onslow Bay, North Carolina. Fish. Oceanogr. $8: 22-36$

Collette, B.B. and Nauen, C.E. (1983) FAO Species Catalogue. Scombrids of the world: an annotated and illustrated catalogue of tunas, mackerels, bonitos and related species known to date. FAO Fish. Synopsis 125 2:1-137.

Coombs, S.H., Pipe, R.K. and Mitchell, C.E. (1981) The vertical distribution of eggs and larvae of blue whiting (Micromesistius poutassou) and mackerel (Scomber scombrus) in the eastern North Atlantic and North Sea. Rapp. P.-v. Reun. Cons. Int. Explor. Mer. 178:188-195.

Crossland, J. (1981) Fish eggs and larvae of the Hauraki Gulf, New Zealand. Fish. Res. Bull. NZ Ministry Agric. Fish. 23:1-61.

Crossland, J. (1982) Distribution and abundance of fish eggs and larvae from the spring and summer plankton of north-east New Zealand, 1976-1978. Fish. Res. Bull. NZ Ministry Agri. Fish. 24:1-59.

Dawson, W.A. (1986) Changes in western mackerel (Scomber scombrus) spawning stock composition during the spawning season. J. Mar. Biol. Assoc. UK 66:367-383.

Dickerson, T.L., Macewicz, B.J. and Hunter, J.R. (1992) Spawning frequency and batch fecundity of chub mackerel, Scomber japonicus, during 1985. CalCOFI Rep. 33:130-140.

Esqueda-Escarcega, G.M.A. (1995) Spatial and temporal distribution of Scomber japonicus larvae in the Sea of Cortez (1984-1988). Sci. Mar. 59:391-397.

Evans, B.S., White, R.W.G. and Ward, R.D. (1998) Genetic identification of asteroid larvae from Tasmania, Australia, by PCR-RFLP. Mol. Ecol. 7:1077-1082.

Field, J.G., Clarke, K.R. and Warwick, R.M. (1982) A practical strategy for analysing multispecies distribution patterns. Mar. Ecol. Prog. Ser. 8:37-52.

Fox, C.J., Taylor, M.I., Pereyra, R., Villasana, M.I. and Rico, C. (2005) TaqMan DNA technology confirms likely overestimation of cod (Gadus morhua L.) egg abundance in the Irish Sea: implications for the assessment of the cod stock and mapping of spawning areas using egg-based methods. Mol. Ecol. 14:879-884.

Fritzsche, R.A. (1978) Development of Fishes of the Mid-Atlantic Bight - An Atlas of Egg, Larval, and Juvenile Stages. Vol. V. Chaetodontidae through Ophidiidae. Fish and Wildlife Series Biological Service Program FWS/OBS-78/12, 340 pp.

Garcia-Vazquez, E., Alvarez, P., Lopez, P. et al. (2006) PCRSSCP of the 16s rRNA gene, a simple methodology for species identification of fish eggs and larvae. In: Recent Advances in the Study of Fish Eggs and Larvae. M.P. Olivar \& J.J. Govoni(eds). Sci. Mar. 70S2, 13-21. 
Gray, C.A. and Miskiewicz, A.G. (2000) Larval fish assemblages in south-east Australian coastal waters: seasonal and spatial structure. Estuar. Coast. Shelf. Sci. 50:549-570.

Hallegraeff, G.M. and Jeffrey, S.W. (1993) Annually recurrent diatom blooms in spring along the New South Wales coast of Australia. Aust. J. Mar. Fresh. Res. 44:325-334.

Hebert, P.D.N., Cywinska, A., Ball, S.L. and de Waard, J.R. (2003) Biological identifications through DNA barcodes. Proc. R. Soc. Lond.B 270:313-322.

Hunter, J.R. and Kimbrell, C. A. (1980) Early life history of Pacific mackerel, Scomber Japonicus. Fish. Bull. 78:89-101.

Ibaibarriaga, L., Irigoien, X., Santos, M. et al. (2007) Egg and larval distributions of seven fish species in north-east Atlantic waters. Fish. Oceanogr. 16:284-293.

Infante, C., Blanco, E., Zuasti, E., Crespo, A. and Manchado, M. (2007) Phylogenetic differentiation between Atlantic Scomber colias and Pacific Scomber japonicus based on nuclear DNA sequences. Genetica 130:1-8.

Keane, J.P. and Neira, F.J.(2008) Larval fish assemblages along the south-eastern Australian shelf: linking mesoscale nondepth-discriminate structure and water masses. Fish. Oceanogr. 17:263-280.

Kramer, D. (1960) Development of eggs and larvae of Pacific mackerel and distribution and abundance of larvae 1952-1956. Fish. Bull. 174:393-438.

de Lafontaine, Y. and Gascon, D. (1989) Ontogenic variation in the vertical distribution of eggs and larvae of Atlantic mackerel (Scomber scombrus). Rapp. P.-v. Reun. Cons. Int. Explor. Mer. 191:137-145.

van der Lingen, C.D., Checkley, D. Jr, Barange, M. and Osgood, K. (1998) Assessing the abundance and distribution of eggs of sardine, Sardinops sagax, and round herring, Etrumeus whiteheadi, on the western Agulhas Bank, South Africa, using a continuous, underway fish egg sampler. Fish. Oceanogr. $7: 35-47$.

van der Lingen, C.D., Hutchings, L., Merkle, D., van der Westhusien, J.J. and Nelson, J. (2001) Comparative spawning habitats of anchovy (Engraulis capensis) and sardine (Sardinops sagax) in the southern Benguela upwelling ecosystem. In: Spatial Processes and Management of Marine Populations. G.H. Krauseet al. (eds). Fairbanks, USA: University of Alaska Sea Grant, AK-SG-01-02, pp. 185-209.

van der Lingen, C.D., Castro, L., Drapeau, L. and Checkley, D. Jr (eds) (2005) Report of a GLOBEC-SPACC Workshop on Characterizing and Comparing the Spawning Habitats of Small Pelagic Fish. GLOBEC Report 21, 33 pp.

Lockwood, S.J., Nichols, J.H. and Dawson, W.A. (1981) The estimation of a mackerel (Scomber scombrus L.) spawning stock size by plankton survey. J. Plankton Res. $3: 217-233$.

Mendiola, D., Alvarez, P., Cotano, U. and Martínez de Murgía, A. (2007) Early development and growth of the laboratory reared north-east Atlantic mackerel Somber scombrus L. J. Fish Biol. 70:911-933.

Morse, W.W. (1980) Spawning: the fecundity of Atlantic mackerel, Scomber scombrus, in the middle Atlantic bight. Fish. Bull. U.S. 78:103-108.

Muck, P., Sandoval de Castillo, O. and Carrasco, S. (1987) Abundance of sardine, mackerel and horse mackerel eggs and larvae and their relationship to temperature, turbulence and anchoveta biomass off Peru. In: The Peruvian Anchoveta and its Upwelling Ecosystem: Three Decades of Change. D. Pauly \& I. Tsukayama(eds). Manila; Philippines: ICLARM. ICLARM Studies and Reviews 15, pp. 268-275.

Neira, F.J., Miskiewicz, G.A. and Trnski, T. (1998) Larvae of Temperate Australian Fishes - Laboratory Guide for Larval Fish Identification. Nedlands: University of Western Australia Press, 474 pp.

Neira, F.J., Keane, J.P., Lyle, J.M. and Tracey, S.R. (2008) Development of eggs and larvae of Emmelichthys nitidus (Percoidei: Emmelichthyidae) in south-eastern Australia, including a temperature-dependent egg incubation model. Estuar. Coast. Shelf. Sci. (in press).

Nilsson, C.S. and Cresswell, G.R. (1981) The formation and evolution of East Australian Current warm core eddies. Progr. Oceanogr. 9:133-183.

Oke, P.R. and Middleton, J.H. (2001) Nutrient enrichment off Port Stephens: the role of the East Australian Current. Cont. Shelf Res. 21:587-606.

Ozawa, T. (1984) The postlarvae of spotted mackerel Scomber australasicus Cuvier (Pisces, Scombridae). Bull. Jpn. Soc. Sci. Fish. 50:1317-1321.

Pegg, G.G., Sinclair, B., Briskey, L. and Aspden, W.J. (2006) MtDNA barcode identification of fish larvae in the southern Great Barrier Reef, Australia. In: Recent Advances in the Study of Fish Eggs and Larvae. M.P. Olivar \& J.J. Govoni(eds). Sci. Mar. 70, S2: 7-12.

Priede, I.G. and Watson, J.J. (1993) An evaluation of the daily egg production method for estimating biomass of Atlantic mackerel (Scomber scombrus). Bull. Mar. Sci. 53:891-911.

Prince, J.D. and Griffin, D.A. (2001) Spawning dynamics of the eastern gemfish (Rexea solandri) in relation to regional oceanography in south-eastern Australia. Mar. Freshw. Res. 52:611-622.

Quinn, G.P. and Keough, M.J. (2002) Experimental Design and Data Analysis for Biologists. Cambridge: Cambridge University Press, 537 pp.

Ridgway, K.R. and Godfrey, J.S. (1997) Seasonal cycle of the East Australian Current. J. Geophys. Res. 102:22921-22936.

Scoles, D.R., Collette, B.B. and Graves, J.E. (1998) Global phylogeography of mackerels of the genus Scomber. Fish. Bull. 96:823-842.

Shao, K.T., Yang, R.S, Chen, K.C. and Lee, Y.S.(2001) An Identification Guide of Marine Fish Eggs from Taiwan. Institute of Zoology, Taipei, Taiwan, Academia Sinica. Taiwan Power Company, 179 pp.

Shao, K.T., Yang, R.S, Chen, K.C. and Wu, J.H. (2002) Identification of marine fish eggs in Taiwan using light microscope, scanning electric microscope and mtDNA sequencing. Mar. Freshw. Res. 53:355-365.

Stratoudakis, Y., Bernal, M., Ganias, K. and Uriarte, A. (2006) The daily egg production method: recent advances, current applications and future challenges. Fish Fish. 7:35-57.

Studholme, A.L., Packer, D.B., Berrien, P.L., Johnson, D.L., Zetlin, C.A. and Morse, W.W.(1999) Atlantic mackerel, Scomber scombrus, life history and habitat characteristics. NOAA Technical Memorandum MNFS-NE-141, 35 pp.

Taylor, M.I., Fox, C., Rico, I. and Rico, C. (2002) Speciesspecific TaqMan probes for simultaneous identification of (Gadus morhua L.), haddock (Melanogrammus aeglefinus L.) and whiting (Merlangius merlangus L.). Mol. Ecol. Notes 2:599-601. 
Tranter, D.J., Carpenter, D.J. and Leech, G.S. (1986) The coastal enrichment effect of the East Australian Current eddy field. Deep Sea Res. 33:1705-1728.

Ward, P., Timmiss, T. and Wise, B. (2001) A review of biology and fisheries for mackerel. Updated Report to the Fisheries Resources Research Fund. Australia: Bureau of Rural Sciences, 120 pp.

Ward, T.M., Staunton-Smith, J., Hoyle, S. and Halliday, I.A. (2003) Spawning patterns of four species of predominantly temperate pelagic fishes in the sub-tropical waters of southern Queensland. Estuar. Coast. Shelf. Sci. 56:1125-1140.

Ward, R.D., Zemlak, T.S., Innes, B.H., Last, P.R. and Hebert, P.D.N. (2005) DNA barcoding of Australia's fish species. Philos. Trans. R. Soc. Lond. B 360:1847-1857.
Ware, D.M. (1977) Spawning time and egg size of Atlantic mackerel, Scomber scombrus, in relation to plankton. J. Fish. Res. Board Can. 34:2308-2315.

Ware, D.M. and Lambert, T.C. (1985) Early life history of Atlantic mackerel (Scomber scombrus) in the southern Gulf of St. Lawrence. Can. J. Fish. Aquat. Sci. 42:577-592.

Watanabe, T. (1970) Morphology and ecology of early stages of life in Japanese common mackerel, Scomber japonicus Houttuyn, with special reference to fluctuation of population. Bull. Tokai Regional Fish. Res. Lab. 62:1-283.

Watanabe, C., Hanai, T., Meguro, K., Ogino, R. and Kimura, R. (1999) Spawning biomass estimates of chub mackerel Scomber japonicus of Pacific subpopulation off Central Japan by a daily egg production method. Nippon Suisan Gakk. 65:695-702. 